\title{
Effect of dehydroepiandrosterone on protein and fat digestibility, body protein and muscular composition in high-fat-diet-fed old rats
}

\author{
Fátima Pérez de Heredia, David Cerezo, Salvador Zamora and Marta Garaulet* \\ Department of Physiology, University of Murcia, Paseo Rector Sabater s/n, Campus de Espinardo, 30100 Murcia, Spain
}

(Received 6 March 2006 - Revised 27 September 2006 - Accepted 4 October 2006)

\begin{abstract}
The main objective of the present study was to examine the effects of dehydroepiandrosterone (DHEA) on the digestive efficiency of dietary protein and fat. Second, we analysed the specific changes in muscle composition induced by the hormone. DHEA was given in the diet $(0.5 \%$, w/w) to 75-week-old, high-fat-fed Sprague-Dawley rats $(n$ 11) for 13 weeks; age- and weight-matched rats fed on the same diet without DHEA supplementation were used as controls $(n 10)$. To determine dietary protein and fat apparent digestibility coefficients, 1 -week $24 \mathrm{~h}$ faecal depositions were collected. In parallel, urine $\mathrm{N}$ was assessed. These assays were performed twice, in the short term (2-week treatment) and in the long term (13-week treatment). Body and gastrocnemius muscle compositions were also analysed. The present results show that DHEA decreased energy intake, body weight, body fat, adipocyte size and number $(P<0 \cdot 001)$. The feed efficiency ratio indicates that DHEA-treated rats were less efficient in transforming nutrients fed into their own biomass. Also, a short-term reduction in protein digestibility $(P<0 \cdot 05)$ and in body-protein degradation $(P<0 \cdot 01)$ was found in DHEA-treated rats, resulting in an increased content of body protein $(P<0 \cdot 05)$. Gastrocnemius muscles were smaller, as a result of fat $(P<0.05)$ but not protein reduction. In conclusion, we confirm the slimming effect of DHEA and, for the first time, we demonstrate that DHEA has an effect at the digestive level. The anti-obesity properties of DHEA could be related to a reduction in protein digestibility in the short term and a protective effect on body protein with a selective mass loss from body fat.
\end{abstract}

Dehydroepiandrosterone: Digestibility: Body protein: Gastrocnemius muscle: Obesity: High-fat diets

Dehydroepiandrosterone (DHEA) and its sulfate, DHEA-S, are the most abundant circulating steroids in man and the precursors for most steroid hormones (Orentreich et al. 1984). Serum concentrations of DHEA and DHEA-S are age dependent; in man, they rapidly increase at puberty, reach their peak levels between 20 and 30 years of age, and then decrease gradually (Yamaji \& Ibayashi, 1969; Orentreich et al. 1984; Vermeulen, 1995; Macario et al. 1999). This evolution, coincident with the incipient loss of physical performance, has led these hormones to be known as 'the hormones of youth' (Nawata et al. 2002).

Far from being just biochemical intermediates, these steroids per se have been reported to have positive effects in the prevention and treatment of certain pathologies, especially the age-related ones, such as cancer (Schwartz et al. 1988; Ratko et al. 1991; Kawai et al. 1995), CVD (Ebeling \& Koivisto, 1994), cognitive deterioration (Yanase et al. 1996), insulin resistance and obesity (Williams et al. 1993).

In man, the action of DHEA on obesity is not generally agreed. Some studies report no relationship between plasma levels of these steroids and body weight and fat (Azziz et al. 1991; Phillips, 1993; Barret-Connor \& Ferrara, 1996; Macario et al. 1999), while others find a negative correlation between serum DHEA-S or DHEA and obesity (De Pergola et al. 1991; Tchernof et al. 1995). Regarding its pharmacological use, some authors doubt that exogenous DHEA has any effect on weight loss in obese human subjects (Clore, 1995). In contrast, others have suggested a role for DHEA-S treatment in fatmass loss (Nestler et al. 1988). Furthermore, DHEA-S plasma levels show a negative correlation with visceral fat distribution in women (Garaulet et al. 2000) and its administration seems to improve glucose tolerance (Haffner \& Valdez, 1994; Richards et al. 2000) and to reduce serum cholesterol and TAG (Macario et al. 1999), so ameliorating these features of the metabolic syndrome.

In rodents, DHEA has been reported to decrease dietary fat and energy intakes as well as body weight and fat content (Taniguchi et al. 1995; Richards et al. 1999; Pham et al. 2000; Abadie et al. 2001; Kajita et al. 2003; Ryu et al. 2003). However, the mechanisms of action of this hormone on body composition are not yet fully understood, although a role in food intake regulation has been suggested (Shepherd \& Clearly, 1984; Abadie et al. 1993; Svec et al. 1995; Wright et al. 1995; Svec \& Porter, 1996; Pham et al. 2000), or even in the utilisation or storage of ingested energy (Clearly et al. 1984; Mohan et al. 1990). In addition, there are studies reporting direct effects of DHEA on muscle, suggesting another mechanism for the hormone action on body composition (Tsuji et al. 1999; Abadie et al. 2001; Aragno et al. 2004; Campbell et al. 2004). However, no specific studies have been found in the literature that focused on the influence of DHEA or DHEA-S on the digestibility of the different macronutrients, i.e. protein, carbohydrates or fat.

\footnotetext{
Abbreviations: DHEA, dehydroepiandrosterone; DHEA-S, dehydroepiandrosterone sulfate; FER, feed efficiency ratio; NPU, net protein utilisation. *Corresponding author: Dr M. Garaulet, fax +3496836 39 63, email garaulet@um.es
} 
In the present study, the main objective was to analyse whether the effects of DHEA on body weight and composition of aged, fat-fed rats are exerted at a digestive level, i.e. dietary protein and fat digestibility or metabolic use. A second objective was to study the specific effects of DHEA in skeletal muscle composition, particularly in the gastrocnemius muscle.

\section{Materials and methods}

\section{Animals and housing conditions}

Twenty-one female Sprague-Dawley rats were provided by our University's animal care facilities, and kept in a temperature-controlled room $\left(24 \pm 2^{\circ} \mathrm{C}\right)$ in a $12 \mathrm{~h}$ light-dark schedule with lights on at 08.00 hours. Rats were bred with a highenergy diet, with $40 \%$ of energy in the form of fat, from 7 weeks of age.

When rats were 72 weeks old and had an average body weight of $345 \pm 6 \mathrm{~g}$, they were housed in individual metabolism cages with free access to water and food. Dietary intake was recorded every $2 \mathrm{~d}$, weighing dispensed, remaining and spilled food. Body weight was monitored weekly. From these measurements, the feed efficiency ratio (FER) was calculated as follows:

$$
\text { FER }=(\text { body weight change }(\mathrm{g}) / \text { food intake }(\mathrm{g})) \times 100 \text {. }
$$

\section{Dietary and hormonal treatments}

The semi-purified high-fat diet (Portillo et al. 2001) is described in Table 1 . This diet was freshly prepared once per week and stored at $5^{\circ} \mathrm{C}$ to avoid rancidity.

After a 3-week adaptation to the metabolism cages, when the rats were 75 weeks old and had an average body weight of $354 \pm 7 \mathrm{~g}$, they were randomly assigned to one of two

Table 1. Composition of the experimental high-fat diet*

\begin{tabular}{|c|c|}
\hline & Content \\
\hline \multicolumn{2}{|c|}{ Component (g/100 g diet) } \\
\hline Palm oil* & 20 \\
\hline Casein* & 20 \\
\hline Maize starch & 24.5 \\
\hline Sucrose $^{*}$ & $24 \cdot 4$ \\
\hline Cellulose* & 5 \\
\hline Mineral mix $†$ & 4.5 \\
\hline Vitamin mix $\dagger$ & 1 \\
\hline Choline $^{\star}$ & 0.2 \\
\hline Methionine* & 0.4 \\
\hline \multicolumn{2}{|c|}{ Nutrient ( $\mathrm{g} / 100 \mathrm{~g}$ diet) } \\
\hline Water & 3.7 \\
\hline Carbohydrate & $50 \cdot 4$ \\
\hline Protein & $18 \cdot 4$ \\
\hline Fat & $19 \cdot 4$ \\
\hline Fibre & 4.4 \\
\hline Minerals & 3.7 \\
\hline Energy (kJ) & $1880 \cdot 1$ \\
\hline \multicolumn{2}{|c|}{$\begin{array}{l}\text { * Palm oil supplied by Croexa (Barcelona, Spain); casein supplied } \\
\text { by Hero (Murcia, Spain); sucrose supplied by a local market; } \\
\text { cellulose (Avicel) supplied by FMC Corp. (Madrid, Spain); cho- } \\
\text { line and methionine supplied by J. Escuder (Barcelona, Spain). } \\
\text { † Mineral and vitamin mixes were formulated according to the } \\
\text { AIN-92 dietary guidelines for laboratory rodents' care (Reeves } \\
\text { et al. 1993) and supplied by Tegasa (Barcelona, Spain) and } \\
\text { Sigma (St Louis, MO, USA). }\end{array}$} \\
\hline
\end{tabular}

experimental groups: the control group ( $n$ 10) and the DHEA group ( $n$ 11). The control group kept on being fed the high-fat diet, without any change, while the DHEA group received the high-fat diet supplemented with DHEA at $0.5 \%$ (w/w) (Roig Farma, S.A., Terrasa, Barcelona, Spain; $99.5 \%$ purity). This hormonal treatment lasted for 13 weeks.

\section{Digestibility of dietary protein and fat}

The digestibility assay provides information on dietary use: the analysis of faecal $\mathrm{N}$ and fat is needed to determine the apparent digestibility coefficients for dietary protein and fat, while urine $\mathrm{N}$ is an index of the metabolic utilisation of body protein.

The assays were conducted on fourteen out of the twentyone animals (seven from the control group and seven from the DHEA group) and consisted of the collection of $24 \mathrm{~h}$ urinary and faecal excretions during 1 week. In faeces, $\mathrm{N}$ and fat contents were determined to further estimate the intestinal digestibility coefficients of dietary protein and fat. Urinary $\mathrm{N}$ and net protein utilisation (NPU) were assessed to obtain information about total protein catabolism. All analyses were performed according to the official methods of the Association of Official Analytical Chemists International (1997).

The $\mathrm{N}$ content of urine was measured by the Kjeldahl method and expressed as mg N/100 g body weight. The N content of faeces was determined following the same procedure, and then protein was calculated by multiplying by the conversion factor $6 \cdot 25$. The fat content of faeces was assessed by diethyl ether extraction in a Soxhlet apparatus (Foss, Hillerød, Denmark), with a previous digestion with hydrochloric acid. Protein and fat faecal excretion were determined and apparent digestibility coefficients (ADC) were calculated as follows:

$$
\operatorname{ADC}(\%)=100 \times\left(N_{i}-N_{f}\right) / N_{i},
$$

where $N_{i}$ is the nutrient intake $(\mathrm{g})$ and $N_{f}$ is the nutrient content of faeces $(\mathrm{g})$. In addition, NPU was calculated as the excreted $\mathrm{N}$ :digested $\mathrm{N}$ ratio, as follows:

$$
\operatorname{NPU}(\%)=100 \times\left(\left(N_{i}-N_{f}\right)-N_{u}\right) / N_{i},
$$

where $N_{u}$ is the nutrient content of urine.

Before the beginning of the hormonal treatment, an assay of digestibility was performed, in order to confirm the homogeneity of the population $\left(\mathrm{A}_{0}\right)$. To study the short- and long-term effects of DHEA treatment on protein and fat digestibility, two more assays were carried out following the same procedure, but at different times. The first one $\left(\mathrm{A}_{1}\right)$ took place 2 weeks after the beginning of the hormonal treatment, and the second $\left(A_{2}\right)$ just at its end, after 13 weeks.

\section{Assessment of body and muscular composition}

At the end of the 13-week experimental period and after an overnight fast, all animals were anaesthetised with diethyl ether and killed by cardiac puncture, at the beginning of the light phase. Blood samples were collected and centrifuged to obtained plasma for DHEA-S concentration determination.

Peri-ovarian, mesenteric and subcutaneous fat depots were dissected, weighed, frozen in liquid $\mathrm{N}_{2}$ and stored at 
$-80^{\circ} \mathrm{C}$. Isolated adipocytes were obtained by digestion of adipose tissue with collagenase $\mathrm{A}$ and filtration through nylon mesh, following the method of Rodbell (1964) with minor modifications by Langin et al. (1991). Fat cell size was measured by optic microscopy, with the aid of a computerised image analysis system (MIP 4.5 Microm Image Processing Software; Consulting Image Digital, S.L., Barcelona, Spain) and the mean diameter was calculated by measuring 200 cells. Adipocyte number was estimated in each depot considering average cell weight and depot weight.

Hindlimb gastrocnemius muscles were dissected, weighed, frozen in liquid $\mathrm{N}_{2}$ and stored at $-20^{\circ} \mathrm{C}$, in order to analyse the effect of DHEA administration on skeletal muscle. To determine whether the actions of DHEA on body weight were tissue specific, the relative gastrocnemius size was calculated as a percentage of total body weight.

Carcasses were homogenised by mincing in a grinder for the analysis of total body fat and protein. Muscle and carcass fat contents were determined in the Sohxlet apparatus, and protein contents were measured by $\mathrm{N}$ determination by the Kjeldahl method and multiplying by $6 \cdot 25$, as described earlier. The sample size for muscle analysis was $0.5 \mathrm{~g}$ for $\mathrm{N}$ quantification and $1.5 \mathrm{~g}$ for fat quantification. Body fat was calculated considering carcass fat and dissected adipose depots, and both body fat and protein were expressed as percentages of total body weight. In parallel, gastrocnemius muscle composition was expressed as percentages of total gastrocnemius weight.

\section{Statistical analysis}

All results are presented as mean values with their standard errors. Statistical analysis was performed using SPSS 12.0 (SPSS Inc., Chicago, IL, USA). Student's $t$ test was used to compare energy intake, FER, circulating DHEA-S values, body weight, fat depots and body and muscle compositions between DHEA and control groups and the two-way ANOVA test (assay $\times$ DHEA treatment) was carried out for comparisons of the digestibility results. In all cases, significance was assessed at the $P<0.05$ level.

\section{Results}

\section{Body weight and fat and energy intake}

In order to know if orally administered DHEA had been absorbed and incorporated into the bloodstream, DHEA-S plasma concentrations were measured, proving the oral treatment to be effective and showing that DHEA-treated rats had significantly higher DHEA-S concentrations than control rats (829.6 (SEM 93.3) and 71.8 (SEM 26.0) ng/ml, respectively; $P<0.0001)$.

Table 2 shows the changes in average body weight and body fat from DHEA and control groups after the hormonal treatment. Weekly body-weight changes in treated and nontreated groups are shown in Fig. 1(A). It can be seen that, although the initial weights were similar in the two experimental groups, final body weight was significantly lower in rats treated with DHEA. In addition, this decrease in body weight started in the first week after the beginning of the treatment and reached statistical significance as soon as in the third week. Body and carcass fat percentages were also reduced
Table 2. Changes in body weight, body fat and cellularity of three different fat depots in the two experimental groups

(Mean values with their standard errors)

\begin{tabular}{|c|c|c|c|c|}
\hline & \multicolumn{2}{|c|}{$\begin{array}{l}\text { Control group } \\
\quad(n 10)\end{array}$} & \multicolumn{2}{|c|}{$\begin{array}{l}\text { DHEA group } \\
\quad(n 11)\end{array}$} \\
\hline & Mean & SEM & Mean & SEM \\
\hline Initial weight (g) & 356 & $11 \cdot 1$ & 351 & $8 \cdot 3$ \\
\hline Final weight $(\mathrm{g})$ & 347 & $16 \cdot 0$ & $306^{\star}$ & $10 \cdot 6$ \\
\hline Body fat $(\%)$ & $25 \cdot 5$ & $2 \cdot 38$ & $12 \cdot 3^{\star \star \star}$ & 0.67 \\
\hline Carcass fat (\%) & $20 \cdot 1$ & 2.06 & $9 \cdot 2^{\star \star \star}$ & 0.57 \\
\hline \multicolumn{5}{|c|}{ Fat depot weight (g) } \\
\hline Peri-ovarian & $7 \cdot 3$ & 1.00 & $3 \cdot 4^{*}$ & 0.29 \\
\hline Mesenteric & 4.8 & 0.71 & $2 \cdot 0^{*}$ & 0.23 \\
\hline Subcutaneous & 9.0 & 1.05 & $2 \cdot 9^{\star}$ & 0.22 \\
\hline \multicolumn{5}{|c|}{ Adipocyte size $(\mu \mathrm{m})$} \\
\hline Peri-ovarian & 90.5 & $5 \cdot 36$ & $74 \cdot 0^{\star}$ & 2.95 \\
\hline Mesenteric & $69 \cdot 6$ & 3.05 & $54 \cdot 7^{\star \star}$ & $3 \cdot 25$ \\
\hline Subcutaneous & $58 \cdot 0$ & 3.85 & $52 \cdot 7$ & 2.42 \\
\hline \multicolumn{5}{|c|}{ Adipocyte number $\left(\times 10^{6}\right)$} \\
\hline Peri-ovarian & 20.5 & 9.99 & $17 \cdot 4$ & 4.03 \\
\hline Mesenteric & $29 \cdot 2$ & 3.88 & 26.9 & 2.69 \\
\hline Subcutaneous & $110 \cdot 1$ & $20 \cdot 38$ & $46 \cdot 1^{*}$ & 6.85 \\
\hline
\end{tabular}

DHEA, dehydroepiandrosterone.

Mean value was significantly different from that of the control group: ${ }^{\star} P<0.05,{ }^{* \star} P<0.01,{ }^{\star \star *} P<0.001$.

following DHEA administration and the reduction affected all fat depots studied. The significant changes found in fat cell size and number with DHEA treatment were depot specific: fat cell size was decreased in visceral (peri-ovarian
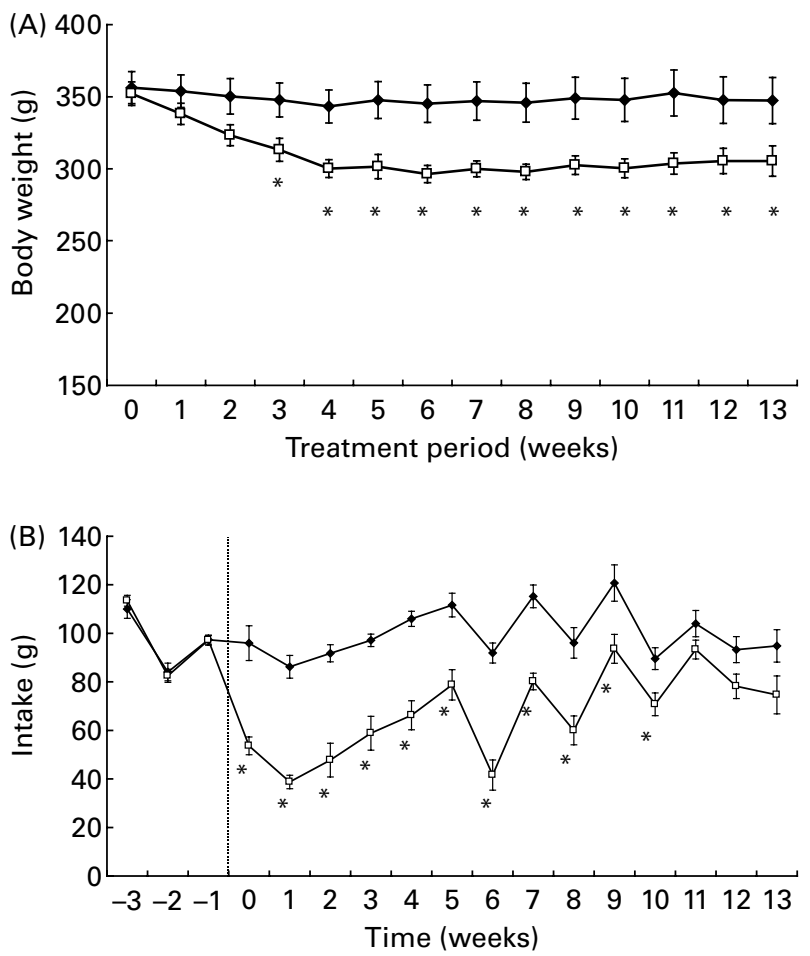

Fig. 1. Body weight $(A)$ and weekly food intake (B) in control (- - ) and dehydroepiandrosterone-treated $(-\square-)$ rats throughout the experimental period. Values are means, with standard errors represented by vertical bars. *Mean value was significantly different from that of the control group $(P<0.05)$. 
and mesenteric) adipose tissue in DHEA rats, while in subcutaneous adipose tissue there was a reduction in adipocyte number (Table 2).

Regarding energy intake, it was smaller in the group that was fed DHEA compared with the control group (Table 3 and Fig. 1(B)). In order to know if the reduction in body weight was due to a diminished energy intake, the FER was calculated. Data show that DHEA-treated rats were less efficient in transforming the nutrients fed into their own biomass (Table 3).

\section{Digestibility assays}

To determine whether the diminished feeding efficiency had a digestive origin, three digestibility assays were performed at different times: before the beginning of the treatment $\left(\mathrm{A}_{0}\right)$; after 2 weeks of treatment or short-term treatment $\left(A_{1}\right)$ and after 13 weeks of treatment or long-term treatment $\left(A_{2}\right)$ (Table 4). Data show that after 2 weeks of hormonal treatment there was a significant reduction in protein digestibility in the treated group (Table 4). Similar results were observed for urinary $\mathrm{N}$ excretion, which was significantly lower in the DHEA-treated rats in the $A_{1}$ assay (short term). In agreement with these data, the NPU was higher in DHEA-treated rats, although differences did not reach statistical signification (Table 5). In the long-term assay $\left(\mathrm{A}_{2}\right)$, we found a similar trend both in protein digestibility and $\mathrm{N}$ excretion, although without statistical significance (Table 5). With regard to fat digestibility, no significant differences were found between the DHEA-treated and non-treated rats, neither in the shortnor in the long-term assays (Table 4).

\section{Body protein and muscular composition}

DHEA treatment exerted a significant and positive effect on total body protein. Indeed, body protein percentage was significantly higher in DHEA-treated rats than in the control ones, although no significant differences were found in the other protein parameters studied, such as muscle protein content and percentage (Table 6).

Regarding relative gastrocnemius weight percentage, significant differences were found between DHEA-treated and non-treated rats, the percentage being higher in the treated group. However, the gastrocnemius weight itself was significantly smaller. The lower weight of DHEA-rats' muscles could be due to the significant reduction of fat content of the muscles from the DHEA rats compared with control ones (Table 6).

\section{Discussion}

The involvement of exogenous DHEA and DHEA-S as antiobesity agents in rodents seems to be generally accepted, although there is still some divergence about the effects on body weight and body-fat loss.

The present study confirms the effectiveness of a DHEA treatment in reducing body weight and the proportion of body fat in aged, high-fat-fed rats. These results are in accordance with other studies which show the anti-obesity properties of this hormone (Mohan et al. 1990; Tagliaferro et al. 1995; Lea-Currie et al. 1997a,b). However, other studies found no effect on body weight (Lea-Currie et al. 1997a,b; Aragno et al. 2004). These differences could be a consequence of the length of the treatment. In the present study, the slimming effect of DHEA was immediate; it was noticeable after just 1 week of hormone administration.

We observed that the effect of DHEA on adipose tissue was depot specific. All adipose regions studied were smaller in DHEA-treated than in control rats, but this reduction was mediated by diminished adipocyte size in mesenteric and peri-ovarian fat depots, while in the subcutaneous adipose tissue it was due to a $2 \cdot 4$-fold drop in fat cell number.

The present results also show a significant effect of DHEA on energy intake. Treated rats reduced their energy intake at the beginning of the experiment and, although it was steadily increased throughout the study, it remained lower than the intake of the control group and total energy consumption was significantly less than that of the control group. This behaviour has been previously observed (Abadie et al. 2001; Ryu et al. 2003), although other authors report no alteration in food intake due to DHEA administration (Hansen et al. 1997). Again, as was postulated for body-fat reduction, the different impact of this hormone on intake could be influenced by the treatment period; in the short term the reduction is rather evident, but normal intake is recovered in the long term (Porter \& Svec, 1995). In the present study, however, this was not the case, since our experimental group ate less than the control one during the 13 weeks of DHEA administration.

In the revised literature, there is disagreement on whether the decreased energy intake could be the reason for the reduction in body weight and fat or if there are other factors influencing this effect. To elucidate this question, we

Table 3. Body-weight change, cumulative intake and feed efficiency ratio (FER) in 13 weeks of the dehydroepiandrosterone (DHEA) treatment period

(Mean values with their standard errors)

\begin{tabular}{|c|c|c|c|c|}
\hline & \multicolumn{2}{|c|}{ Control group (n 10) } & \multicolumn{2}{|c|}{ DHEA group ( $n 11)$} \\
\hline & Mean & SEM & Mean & SEM \\
\hline Body-weight change (g) & -9 & $11 \cdot 0$ & $-46^{\star}$ & $9 \cdot 6$ \\
\hline Cumulative food intake $(\mathrm{g})$ & 1300 & $50 \cdot 5$ & $882^{\star \star *}$ & 41.0 \\
\hline Cumulative energy intake (kJ) & 24441 & $949 \cdot 4$ & $16582^{\star \star *}$ & $767 \cdot 1$ \\
\hline FER $(\%) \dagger$ & -1.0 & 1.03 & $-5 \cdot 4^{\star}$ & $1 \cdot 20$ \\
\hline
\end{tabular}

Mean value was significantly different from that of the control group: ${ }^{\star} P<0.05,{ }^{\star \star \star} P<0.001$. †FER $=($ weight change $(\mathrm{g}) /$ diet fed $(\mathrm{g}))$. 
Table 4. Protein and fat apparent digestibility coefficients in the three digestibility assays

(Mean values with their standard errors)

\begin{tabular}{|c|c|c|c|c|}
\hline & \multicolumn{2}{|c|}{ Control group ( $n 7$ ) } & \multicolumn{2}{|c|}{ DHEA group $(n 7)$} \\
\hline & Mean & SEM & Mean & SEM \\
\hline \multicolumn{5}{|c|}{ Protein digestibility (\%) } \\
\hline$A_{0}$ & $89 \cdot 1$ & 2.00 & 91.5 & 0.66 \\
\hline$A_{1}$ & $92 \cdot 3$ & 0.72 & $86 \cdot 9^{*}$ & $2 \cdot 17$ \\
\hline$A_{2}$ & 93.5 & 0.81 & $90 \cdot 8$ & 1.34 \\
\hline \multicolumn{5}{|c|}{ Fat digestibility (\%) } \\
\hline$A_{0}$ & 75.9 & $3 \cdot 12$ & 78.4 & 2.29 \\
\hline$A_{1}$ & $88 \cdot 6$ & 0.97 & $87 \cdot 0$ & 0.97 \\
\hline$A_{2}$ & $90 \cdot 6$ & 0.79 & $90 \cdot 8$ & 1.91 \\
\hline
\end{tabular}

DHEA, dehydroepiandrosterone; $A_{0}$, assay before the beginning of the treatment; $A_{1}$, assay after 2 weeks of treatment; $A_{2}$, assay after 13 weeks of treatment. ${ }^{*}$ Mean value was significantly different from that of the control group $(P<0.05)$.

calculated the FER. The present results show that FER was higher in control than in treated rats, indicating the DHEAtreated rats were less efficient in transforming the nutrients fed into their own biomass. In this sense, the study by Ryu et al. (2003) showed that rats given DHEA lost more weight than their pair-fed, non-treated counterparts, even when the same energy intake was consumed. These data suggest that the weight loss observed in the DHEA-treated rats was not due exclusively to lower food intake, but to other processes that were being altered by DHEA.

The mechanisms by which DHEA acts on body composition still remain to be clarified. Authors have suggested different targets for the anti-obesity properties of DHEA, such as alteration of pre-adipocyte proliferation and differentiation (LeaCurrie et al. 1998), increase of thermogenesis in brown and white adipose tissues (Ryu et al. 2003), or changes in the central regulation of food intake (Tagliaferro et al. 1986; Wright et al. 1995; Svec \& Porter, 1997; Gillen et al. 1999). However, it has not been reported yet whether DHEA affects the digestive process.

For that reason, for the first time, we analysed the possible effect of DHEA administration on the digestion and/or absorption of dietary protein and fat. The present results showed a significant reduction in protein digestibility in the short-term treatment with DHEA. No significant effect was found on

Table 5. Urine nitrogen excretion and net protein utilisation (NPU) in the digestibility assays

(Mean values with their standard errors)

\begin{tabular}{|c|c|c|c|c|}
\hline & \multicolumn{2}{|c|}{ Control group ( $n 7)$} & \multicolumn{2}{|c|}{ DHEA group ( $n 7)$} \\
\hline & Mean & SEM & Mean & SEM \\
\hline \multicolumn{5}{|c|}{$\mathrm{N}$ excretion (mg N/100 g body weight) } \\
\hline $\mathrm{A}_{0}$ & $581 \cdot 7$ & 18.98 & $589 \cdot 3$ & $22 \cdot 14$ \\
\hline$A_{1}$ & 553.5 & $17 \cdot 10$ & $452 \cdot 5^{\star \star}$ & $13 \cdot 84$ \\
\hline $\mathrm{A}_{2}$ & $642 \cdot 5$ & $22 \cdot 61$ & $624 \cdot 6$ & $17 \cdot 62$ \\
\hline \multicolumn{5}{|c|}{ NPU (\% $\mathrm{N}$ retained $/ \mathrm{N}$ ingested) } \\
\hline $\mathrm{A}_{1}$ & $15 \cdot 2$ & $2 \cdot 04$ & $20 \cdot 9$ & $4 \cdot 03$ \\
\hline $\mathrm{A}_{2}$ & $28 \cdot 7$ & 2.50 & $31 \cdot 0$ & 3.91 \\
\hline
\end{tabular}

DHEA, dehydroepiandrosterone; $A_{0}$, assay before the beginning of the treatment; $A_{1}$, assay after 2 weeks of treatment; $A_{2}$, assay after 13 weeks of treatment.

${ }^{\star \star}$ Mean value was significantly different from that of the control group $(P<0.01)$.
Table 6. Body protein and muscle composition (Mean values with their standard errors)

\begin{tabular}{|c|c|c|c|c|}
\hline & \multicolumn{2}{|c|}{$\begin{array}{l}\text { Control group } \\
\quad(n 10)\end{array}$} & \multicolumn{2}{|c|}{$\begin{array}{l}\text { DHEA group } \\
\quad(n 11)\end{array}$} \\
\hline & Mean & SEM & Mean & SEM \\
\hline Body protein (g) & $60 \cdot 6$ & $2 \cdot 19$ & $62 \cdot 3$ & $1 \cdot 72$ \\
\hline Body protein (\%) & $18 \cdot 3$ & 0.74 & $22 \cdot 1^{\star}$ & 0.44 \\
\hline Gastrocnemius weight (g) & $2 \cdot 2$ & 0.40 & $2 \cdot 0^{\star \star}$ & 0.05 \\
\hline $\begin{array}{l}\text { Relative gastrocnemius } \\
\text { weight }(\%) \dagger\end{array}$ & 0.65 & 0.020 & $0 \cdot 70^{*}$ & 0.017 \\
\hline Muscle protein (g) & 0.48 & 0.013 & 0.45 & 0.015 \\
\hline Muscle protein (\%) & $22 \cdot 2$ & 0.19 & $22 \cdot 3$ & 0.12 \\
\hline Muscle fat $(\mathrm{g})$ & 0.07 & 0.010 & $0.04^{\star}$ & 0.003 \\
\hline Muscle fat (\%) & $3 \cdot 0$ & 0.38 & $1 \cdot 9^{\star}$ & 0.09 \\
\hline
\end{tabular}

DHEA, dehydroepiandrosterone.

Mean value was significantly different from that of the control group: ${ }^{\star} P<0.05$, ${ }^{\star \star} P<0.01$.

$†$ Gastrocnemius weight expressed as a percentage of total body weight.

fat digestibility neither in the short- nor in the long-term assay. These data as a whole could indicate that the anti-obesity properties of DHEA could be related to a decreased digestibility of dietary protein, but not to a specific action on the dietary fat digestibility.

Further studies are needed in order to find out how DHEA treatment affects protein digestibility, whether it interferes with the digestive process, interacting for instance with receptors in protease-secreting pancreatic cells or altering the function of peptidases in the luminal cell membranes. Perhaps DHEA acts at the absorptive level, interfering with amino acid and oligopeptide transporters (Martínez de Victoria et al. 2005).

Another mechanism for the anti-obesity effects of DHEA and DHEA-S could be mediated by altered utilisation of ingested macronutrients (Clearly et al. 1984; Mohan et al. 1990). We determined $\mathrm{N}$ urinary excretion and NPU, so as to estimate the metabolic degradation of proteins. DHEA supplementation was accompanied by a reduction in the urinary excretion of $\mathrm{N}$ in the short term. The DHEA-related decrease of urinary $\mathrm{N}$ excretion, together with the preserved NPU in spite of the lower food intake and body-mass loss, suggest a protective effect of DHEA on body protein. The fact that the reduction in dietary protein digestibility was followed by a decrease in $\mathrm{N}$ excretion could be a consequence of a possible compensatory effect of DHEA on protein balance.

To fully understand the impact of the previous results on body protein, we analysed total body protein and muscle composition and found that the percentage of body protein was significantly greater in DHEA-treated rats than in controls. Because of its accessibility, the gastrocnemius muscle has been previously studied to analyse the specific effects of DHEA on skeletal muscle (Hansen et al. 1997; Aragno et al. 2004; Campbell et al. 2004). In the present study, a larger gastrocnemius size relative to total body mass was found in DHEA-treated rats compared with control ones. However, regarding gastrocnemius muscle itself, it was smaller. To search for a possible explanation for these results, the gastrocnemius muscle composition was analysed and data showed that the fat content of the muscle was reduced up to a third, while protein content was not altered. This suggests that the 
lower muscle weight in the DHEA group was due to the fat loss provoked by the hormonal treatment specifically in skeletal muscle tissue. These findings indicate that DHEA acts directly on skeletal muscle. In fact, Tsuji et al. (1999) found two specific receptor sites for DHEA-S in skeletal muscle, and Liu \& Dillon (2002) described a G-protein-linked membrane receptor for DHEA. Also, DHEA has been described to exert metabolic effects on skeletal muscle, such as stimulation of glucose uptake (Campbell et al. 2004), changes in fatty acid profile (Abadie et al. 2001) and improvement of muscular function (Aragno et al. 2004).

In conclusion, the present results confirm that DHEA administration in aged rats fed a high-fat diet significantly reduces energy intake, body weight and body fat, with selective changes in fat cell size and number depending on the fat depot. We demonstrated for the first time that DHEA exerts a specific action at a digestive level. In the short term, DHEA treatment is followed by a reduction in protein digestibility compensated by a decrease in urine $\mathrm{N}$ excretion, indicating changes in protein digestibility and in catabolism. As a consequence, both body and muscle compositions were affected, showing an important reduction in fat content and preservation of protein content. It can be therefore suggested that the anti-obesity and antiageing properties of DHEA could be related to a reduction in protein digestibility and a protective effect on body protein, with a selective mass loss from body fat, and that DHEA's properties vary depending on the treatment length.

\section{Acknowledgements}

The authors acknowledge the companies Hero S.L. (Murcia, Spain), Norte-CRSA (Barcelona, Spain) and Tegasa S.L. (Barcelona, Spain), and the Spanish Ministry of Education and Culture, for their economical and technical support. Both F. P. De H and D. C have equally contributed to the elaboration of the present study.

\section{References}

Abadie JM, Malcom GT, Porter JR \& Svec F (2001) Dehydroepiandrosterone alters Zucker rat soleus and cardiac muscle lipid profiles. Exp Biol Med 226, 782-789.

Abadie JM, Wright BG, Correa G, Browne ES, Porter JR \& Svec F (1993) Effect of dehydroepiandrosterone on neurotransmitter levels and appetite regulation of the obese Zucker rat. The Obesity Research Program. Diabetes 42, 662-669.

American Organization of Analytical Chemists International (1997) Official Methods of Analysis of AOAC International, [PA Cunniff, editor].16th ed. Gaithersburg, MD: AOAC International.

Aragno M, Mastrocola R, Catalano MG, Brignardello E, Danni O \& Boccuzzi G (2004) Oxidative stress impairs skeletal muscle repair in diabetic rats. Diabetes 53, 1082-1088.

Azziz R, Zacur HA, Parker CR Jr, Bradley EL Jr \& Boots RL (1991) Effect of obesity on the response to acute adrenocorticotropin stimulation in eumenorrheic women. Fertil Steril 56, 427-433.

Barret-Connor E \& Ferrara A (1996) Dehydroepiandrosterone, dehydroepiandrosterone sulphate, obesity, waist-hip ratio, and non-insulin-dependent diabetes in postmenopausal women: the Rancho Bernardo Study. J Clin Endocrinol Metab 81, 59-64.

Campbell CS, Caperuto LC, Hirata AE, Araujo EP, Velloso LA, Saad MJ \& Carvalho CRO (2004) The phosphatidylinositol/AKT/atypical PKC pathway is involved in the improved insulin sensitivity by DHEA in muscle and liver of rats in vivo. Life Scien 76, 57-70.
Clearly MP, Billheimer J, Finan A, Sartin JL \& Schwartz AG (1984) Metabolic consequences of dehydroepiandrosterone in lean and obese adult Zucker rats. Horm Metab Res 16, 43-46.

Clore JN (1995) Dehydroepiandrosterone and body fat. Obes Res 3, 613-616.

De Pergola G, Giagulli VA, Garruti G, Cospite MR, Giorgino F, Cignarelli M \& Giorgino R (1991) Low dehydroepiandrosterone replacement therapy in postmenopausal women. Metabolism 40, 187-190.

Ebeling P \& Koivisto VA (1994) Physiological importance of dehydroepiandrosterone. Lancet 343, 1479-1481.

Garaulet M, Pérez-Llamas F, Fuente T, Zamora S \& Tebar FJ (2000) Anthropometric, computed tomography and fat cell data in an obese population: relationship with insulin, leptin, tumor necrosis factor- $\alpha$, sex hormone-binding globulin and sex hormones. Eur $J$ Endocrinol 143, 657-666.

Gillen G, Porter JR \& Svec F (1999) Synergistic anoretic effect of dehydroepiandrosterone and D-fenfluramine on the obese Zucker rat. Physiol Behav 67, 173-179.

Haffner SM \& Valdez RA (1994) Decreased testosterone and dehydroepiandrosterone sulphate concentrations are associated with increased insulin and glucose concentrations in nondiabetic men. Metabolism 43, 599-603.

Hansen PA, Han DH, Nolte LA, Chen M \& Holloszy JO (1997) DHEA protects against visceral obesity and muscle insulin resistance in rats fed a high-fat diet. Am $J$ Physiol 273, R1704-R1708.

Kajita K, Ishizuka T, Muna T, Miura A, Ishiwaza M, Kanoh Y, Kawai Y, Natsume Y \& Yashuda K (2003) Dehydroepiandrosterone down-regulates the expression of peroxisome proliferator-activated receptor- $\gamma$ in adipocytes. Endocrinology 144, 253-259.

Kawai S, Yahata N, Nishida S, Nagai K \& Mizushima Y (1995) Dehydroepiandrosterone inhibits B16 mouse melanoma cell growth by induction of differentiation. Anticancer Res 15, 427-431.

Langin D, Portillo MP, Saulnier-Blache JS \& Lafontan M (1991) Coexistence of three $\beta$-adrenoceptor subtypes in white fat cells of various mammalian species. Eur J Pharmacol 199, 291-301.

Lea-Currie YR, Wen P \& McIntosh MK (1997a) Dehydroepiandrosterone-sulphate (DHEAS) reduces adipocyte hyperplasia associated with feeding rats a high-fat diet. Int J Obes Relat Metab Disord 21, $1058-1064$.

Lea-Currie YR, Wen P \& McIntosh MK (1998) Dehydroepiandrosterone reduces proliferation and differentiation of 3T3-L1 preadipocytes. Biochem Biophys Res Commun 248, 497-504.

Lea-Currie YR, Wu SM \& McIntosh MK (1997b) Effects of acute administration of dehydroepiandrosterone-sulphate on adipose tissue mass and cellularity in male rats. Int J Obes Relat Metab Disord 21, 147-154.

Liu D \& Dillon JS (2002) Dehydroepiandrosterone activates endothelial cell nitric-oxide synthase by a specific plasma membrane receptor coupled to $\mathrm{G}_{\mathrm{i} 2,3}$. J Biol Chem 277, 21379-21388.

Macario M, Mazza E, Ramunni J, Oleandri SE, Savio P, Grotto S, Rosetto R, Procopio M, Gauna C \& Ghigo E (1999) Relationship between dehydroepiandrosterone sulphate and anthropometric, metabolic and hormonal variables in a large cohort of obese women. J Clin Endocrinol 50, 595-600.

Martínez de Victoria E, Mañas M \& Yago MD (2005) Fisiología de la digestión (Physiology of digestion). In Tratado de Nutrición. I. Bases Fisiológicas y Bioquímicas de la Nutrición, pp. 249-295 [A Gil, editor]. Madrid: Grupo Acción Médica.

Mohan PF, Ihnen JS, Levin BE \& Clearly MP (1990) Effects of dehydroepiandrosterone treatment in rats with diet-induced obesity. $J$ Nutr 120, 1103-1114.

Nawata H, Yanase T, Goto K, Okabe T \& Ashida K (2002) Mechanism of action of anti-aging-DHEA and the replacement of DHEA-S. Mech Ageing Dev 123, 1101-1106. 
Nestler JE, Barlascini CO, Clore JN \& Blackard WG (1988) Dehydroepiandrosterone reduces serum low density lipoprotein levels and body fat but does not alter insulin sensitivity in normal men. $J$ Clin Endocrinol Metab 66, 57-61.

Orentreich N, Brind JL, Rizer RL \& Vogelman JH (1984) Age changes and sex differences in serum dehydroepiandrosterone sulphate concentrations throughout adulthood. J Clin Endocrinol Metab 59, 551-555.

Pham J, Porter J, Svec D, Eiswirth C \& Svec F (2000) The effect of dehydroepiandrosterone on Zucker rats selected for fat food preference. Physiol Behav 70, 431-441.

Phillips GB (1993) Relationship between serum sex hormones and glucose-insulin-lipid defect in men with obesity. Metabolism 42, $116-120$.

Porter J \& Svec F (1995) DHEA diminishes fat food intake in lean and obese Zucker rats. Ann N Y Acad Sci 774, 329-331.

Portillo MP, Chavarri M, Durán D, Rodríguez VM \& Macarulla MT (2001) Differential effects of diets that provide different lipid sources on hepatic lipogenic activities in rats under ad libitum or restricted feeding. Nutrition 17, 467-473.

Ratko TA, Detrisac CJ, Mehta RG, Kelloff GJ \& Moon RC (1991) Inhibition of rat mammary gland chemical carcinogenesis by dietary dehydroepiandrosterone or a fluorinated analogue of dehydroepiandrosterone. Cancer Res 51, 481-486.

Reeves PG, Nielsen FH \& Fahey GC Jr (1993) AIN-93 purified diets for laboratory rodents: final report of the American Institute of Nutrition Ad Hoc Writing Committee on the reformulation of the AIN-76A rodent diet. J Nutr 123, 1939-1951.

Richards RJ, Porter JR \& Svec F (1999) Long-term oral administration of dehydroepiandrosterone has different effects on energy intake of young lean and obese male Zucker rats when compared to controls of similar metabolic body size. Diabetes Obes Metab 1, 233-239.

Richards RJ, Porter JR \& Svec F (2000) Serum leptin, lipids, free fatty acids and fat pads in long-term dehydroepiandrosterone-treated Zucker rats. Proc Soc Exp Biol Med 223, 258-262.

Rodbell M (1964) Metabolism of isolated fat cells I. Effects of hormones on glucose metabolism and lipolysis. J Biol Chem 239, 375-380.

Ryu JW, Kim MS, Kim CH, Song KH, Park JY, Lee JD, Kim JB \& Lee KU (2003) DHEA administration increases brown fat uncoupling protein 1 levels in obese OLETF rats. Biochem Biophys Res Commun 303, 726-731.

Schwartz AG, Whitcomb JM, Nyce JW, Lewbart ML \& Pashko LL (1988) Dehydroepiandrosterone and structural analogs: a new class of cancer chemopreventive agents. Adv Cancer Res 51, $391-424$.
Shepherd A \& Clearly MP (1984) Metabolic alterations after dehydroepiandrosterone treatment in Zucker rats. Am J Physiol 246, E123-E128.

Svec F, Hilton CW, Wright B, Browne E \& Porter JR (1995) The effect of DHEA given chronically to Zucker rats. Proc Soc Exp Biol Med 209, 92-97.

Svec F \& Porter J (1996) Effect of DHEA on macronutrient selection by Zucker rats. Physiol Behav 59, 721-727.

Svec F \& Porter J (1997) The effect of dehydroepiandrosterone (DHEA) on Zucker rat food selection and hypothalamic neurotransmitters. Psychoneuroendocrinology 22, Suppl. 1, S57-S62.

Tagliaferro AR, Davis JR, Truchon S \& Van Hamont N (1986) Effects of dehydroepiandrosteron acetate on metabolism, body weight and composition of male and female rats. J Nutr 116, 1977-1983.

Tagliaferro AR, Ronan AM, Payne J, Meeker LD \& Tse S (1995) Increased lipolysis to $\beta$-adrenergic stimulation after dehydroepiandrosterone treatment in rats. Am J Physiol 268, R1374-R1380.

Taniguchi S, Yanase T, Haji M, Ishibashi K, Takayanagi R \& Nawata H (1995) The antiobesity effect of dehydroepiandrosterone in castrated or noncastrated obese Zucker male rats. Obes Res $\mathbf{3}$, 639S-643S.

Tchernof A, Despres JP, Belanger A, Dupont A, Prud'homme D, Morjani S, Lupien PJ \& Labrie F (1995) Reduced testosterone and adrenal C19 steroid levels in obese men. Metabolism 44, 513-519.

Tsuji K, Furutama D, Tagami M \& Ohsawa N (1999) Specific binding and effects of dehydroepiandrosterone sulphate (DHEA-S) on skeletal muscle. Possible implications for DHEA-S replacement therapy in patients with miotonic dystrophy. Life Sci??? 65, $17-26$.

Vermeulen A (1995) Dehydroepiandrosterone sulphate and aging. Ann N Y Acad Sci 774, 121-127.

Williams DP, Boyden TW, Pamenter RW, Lohman TG \& Going SB (1993) Relationship of body fat percentage and fat distribution with dehydroepiandrosterone sulphate in premenopausal females. J Clin Endocrinol Metab 77, 80-85.

Wright BE, Svec F \& Porter JR (1995) Central effects of dehydroepiandrosterone in Zucker rats. Int J Obes 19, 887-892.

Yamaji T \& Ibayashi H (1969) Plasma Dehydroepiandrosterone sulphate in normal and pathological conditions. J Clin Endocrinol 29, 273-278.

Yanase T, Kukahori M, Taniguchi S, Nishi Y, Sakai Y, Takayanagi R, Heji M \& Nawata H (1996) Serum dehydroepiandrosterone (DHEA) and DHEA-sulphate (DHEA-S) in Alzheimer's disease and in cerebrovascular dementia. $J$ Endocrinol 43, 119-123. 